\title{
PRICE RISK MANAGEMENT USING BY A SPECIFIED FUTURES MODEL
}

\author{
László Kozár PhD
}

\section{Budapest Business School, Department of Commerce}

Annotation. The principal achievement of this paper is to introduce the operation of a specified 'Futures' model and it's practice for decisionmakers of financial institutes through an example based on the price data's of grain futures market from EU assessment 2004 to these days in Hungary.

Based on a theoretical foundation, the calculation model was developed in order to assist short and long-term marketing decisions. The economical basis of the model is the combinative use of two market institutions: public warehousing and futures market.

This electronically developed and working model 'using excel background 'allows all of the participants of the market: producers, consumers, banks and traders, to use this model in immediate calculations. In addition it helps in order to establish the own business strategy. The model can be used to analyze price influencing factors therefore; it can also be used for policy-making decisions for market participants as well as banks dealing with trade financing activity.

Key words: Renewable energy resources, Solid biomass utilization

\section{Introduction}

The present practice of Lombard financing has been developed for more than twenty years, and by now it has became a day-by-day used financing system. Most of the Hungarian commercial banks are dealing with this type of business.

The Futures Grain Market is in a special situation in Hungary. This market - organized according to the large American Exchanges - corresponds to the strictest expectations by its service, technique, organization and guaranties.

The entire market uses the prices of the given Futures Market as target prices for production agreements, trading contracts as well as Lombard credit financing, and there are participants in the market, from the hedging to the speculating side, as well. This market has a bigger turnover in grain futures contracts than the other European markets such as Marché A Terme d'Instruments Financiers (MATIF), and the other members of the EURONET.

The institutes of public warehousing and futures market are available for the participants on the grain market in Hungary and in several other European countries. The combination of possibilities offered by the two institutes gives the biggest chance to eliminate price risks. In the case of Lombard credits, it gives the best opportunity for both the borrower and the bank, namely: the borrower can have the highest credit amount as the lowest risk for the bank. This construction is called as a Lombard credit with a futures hedge background.

The most important basic information required to do business is the price of the commodity. This determines the profit of the business and the possible financing risk from the banks point of view.
There is no such a thing as ,average” price information, because of the parity, storage, finance and logistics. Knowing the special conditions of a given market, it is possible, however, to prepare precise price calculations for selling or purchasing as well as financing decisions for that market.

To find the relevant answer to these questions, a calculation model was created and all of the prices influencing factors are built in.

The goal of using this model from the sellers and buyers point of view is to calculate daily price information to decide on immediate selling/buying or a postponed selling/buying of the commodity, based on public warehousing and futures hedge information.

The financial institute - depending on the momentary position - can easily become the same selling/buying participant of the market as the others. Because of this the service of the two market institutes as Futures Exchange and Public Warehousing and the introduced Futures model, based on the functions of these institutes' can offer the price risk management possibility for the bank as well.

\section{Methodology of the futures model}

The function of the model is to give up-to-date price information based on the principles described above and daily information about price influencing factors for any participant of the market.

\subsection{Inputs of the model}

The inputs of the model can be shared into two parts: the medium-term principal inputs (e.g. railway tariffs), and the daily-modified information (e.g. currency exchange rate). 
The main inputs are, as below:

Primary cost: Pc: $(€ t)$ the cost of the production of one metric ton of the commodity (in local currency). This is the basis for the price calculation (in the case of a producer).

In case of consumer: Purchasing price: Pp (in local currency).

In case of trader: $\mathbf{P p}$, or Selling price: $\mathbf{S p}$ (in chosen foreign currency).

The price calculation is prepared in one direction in the case of a producer and consumer, but it can be prepared in two directions, as well, in the case of a trader.

Foreign currency: Fc: $(€ c)$ the currency of the offer or the contract. It is usually USD, but any other currency can be used.

Inputs, connected to the storage:

Sf: storage fee (€month), in the case of self - owned storage capacity its primary cost per ton.

St: storage time (month).

Ff: fumigation fee ( $€$ case).

Fp: fumigation period (case).

Inputs, connected to public warehousing:

Wf: warehouse fee ( $€$ month).

Wp: warehousing period (month).

Wo: other additional costs, for example: additional insurance cost $(€ \mathrm{t})$.

\section{Inputs, connected to financing:}

Ir: interest rate of the financing (\%/year, the real rate according to the credit contract, or the average bank interest rate).

Fp: financing period (month).

Fo: other financing costs: additional bank fees $(€ t)$.

\section{Inputs, connected to Commodity Exchange:}

Bf: Brokerage fee, containing the direct fee of Brokerage Company, the fee of Exchange and the fee of Clearing House $(€ \mathrm{t})$.

Id: interest of daily exchange rate differences: (\%/year) $=\mathbf{I r}$.

Pr+, Pr0, Pr-, direction of financing of the daily exchange rate differences.

Fp: Futures period (month), the real open period of the futures contract.

\section{Inputs, connected to transportation:}

Rd: Railway distance: $(\mathrm{km})$, distance from the actual loading point to the border.

Cl: Carriage loading: cost of the loading of railway carriage $(€ \mathrm{t})$.

Rf: Railway freight: the official freight tariffs of the actual Railway Company (€t).

Tf: Truck Freight: $(€ \mathrm{t} / \mathrm{km})$, freightage of the Truck Company.

Td: Trucking distance: $(\mathrm{km})$, the exact carriage distance by truck.

Tl: Truck loading: cost of the loading of truck $(€ \mathrm{t})$.
Inputs, at the port $(€ t)$ :

L: Loading, from truck or rail carriage into the ship/barge.

S: Scaling, the fee of official scaling.

W: Wharfage, the fees of using wharf during loading.

D: Documentation, costs of documents issuing at the port (duty, etc.).

\section{Quality and health certificates ( $(1 \mathrm{t})$ : \\ Q: The fee of Quality Certificate. \\ PI: The fee of local Phytosanitary Certificate. \\ Pe: The fee of export Phytosanitary Certificate. \\ Ve: The fee of export Veterinary Certificate.}

Profit: P: the amount of desired profit $(€ t)$.

\subsection{Outputs of the model}

The model uses the information of principal database first. The pre-calculatory outputs of this calculation gives immediate information for the user, and the final cost and price calculation will be based on these results, as well as the other primary inputs (see above).

The pre-calculation outputs are, as follows:

Storage cost, $\mathbf{S}$ : (€t)

Public Warehousing cost, W: $(€ \mathrm{t})$

Financing cost, $\mathbf{F}$ : $(€ \mathrm{t} \mathrm{t})$

Cost of the Commodity Exchange, E: $(€ t)$.

The model calculates the cost of the daily financing based on the daily exchange rate differences. In case of:

E1 (Pr+): the futures position needs financing during the whole period, which is not more than 50 per cent, according to long-term practice.

E2 (Pr-): the opposite situation, the exchange price difference generates income.

The possibilities of E1 and E2 are the similar in the daily business.

E3 (Pr0): the costs and incomes eliminate each other.

\section{Railway cost, $\mathbf{R}:(€ \mathbf{t})$}

Railway costs cannot be calculated on a $€ \mathrm{~km}$ basis, because the freight cost is not linear with the length of transportation. Because of this, the model uses the official freight tariffs of the actual Railway Company as a principal data base, and chooses the actual cost according to the railway distance.

The loading of railway carriage is not the part of the railway cost, since it is an independent output.

Trucking cost, $\mathbf{T}:(€ \mathrm{t})$

Cost of the port, $P$ : $(€ \mathrm{t})$

Agent's cost, A: $(€ \mathrm{t})$

Foreign currency, Fc: $(€ c)$ the currency of the offer or the contract. It is usually \$, but any other currencies can also be used. 
Final calculation can be prepared after the pre-calculation phase, using the chosen pre-calculation outputs and the other chosen inputs, as a database.

\section{Final outputs are, as below:}

Primary cost, Pc: ( $€ \mathrm{t}$ ) the cost of the production of one metric ton of the commodity (in local currency). This is the basis for the price calculation (in case of a producer).

In case of a consumer: Purchasing price: Pp (in local currency).

In case of a trader: $\mathbf{P p}$, or Selling price: $\mathbf{S p}$ (in chosen foreign currency).

In case of a seller the final output is the selling price: $\mathrm{Sp}$ in $€$, and in the given foreign currency, as well. The model shows the actual parity of the INCOTERMS, too.

In case of a buyer the final output is the Purchasing cost: Pc in $€$ which contains the purchasing price and the additional costs of purchasing.

In case of a trader the final output is the selling price: $\mathrm{Sp}$ in the given foreign currency if there is Purchasing price: $\mathrm{Pp}$ in the input side, or Purchasing price: $\mathrm{Pp}$ in $€$ if there is a selling price: $\mathrm{Sp}$ at the input side.

If there is no price information on the input side, the output is the logistic cost: Lc in the given foreign currency. The model shows the parity of INCOTERMS, too, according to the actual price information.

\section{Practic of the model}

Risk sensibility is the most important question in trade/commodity - financing situations from banks point of view. To avoid risk banks usually chose so-called secure financing constructions with low income possibility instead of commodity - financing with high risk and high profitability.

Opposite of this marketing strategy we can declare that using suitable price risk management practice, combination of the two institution, trade - financing constructions contains much higher profitability without higher level of risk.

Through investigation of futures and spot prices fluctuation of Hungarian grain market between 2004 and 2009 and using calculation model with real price data I try to justify the statement above.

\subsection{Grain price fluctuation from $E U$ assessment 2004 to these days}

Dealing with grain market investigation it is plausible to analyze the price information of these period focusing the price explosion and collapse in 2007-2008.

The figure 1 and 2 are the charts of corn and wheat prices from 2004 to 2009.

According to the charts we can quote that immediately after the assessment the grain prices decreased to the intervention level. From the autumn of 2006 the price trend changed to increasing. After the price explosion of 2007 and the price collapse of 2008 prices returned to the average price

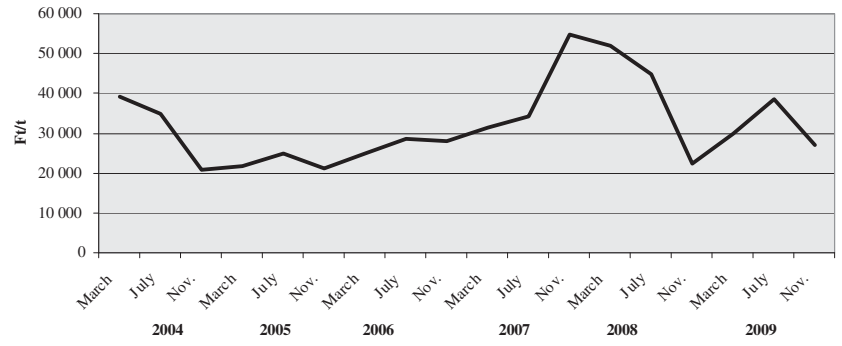

Figure 1: Corn prices in Hungary 2004-2009.

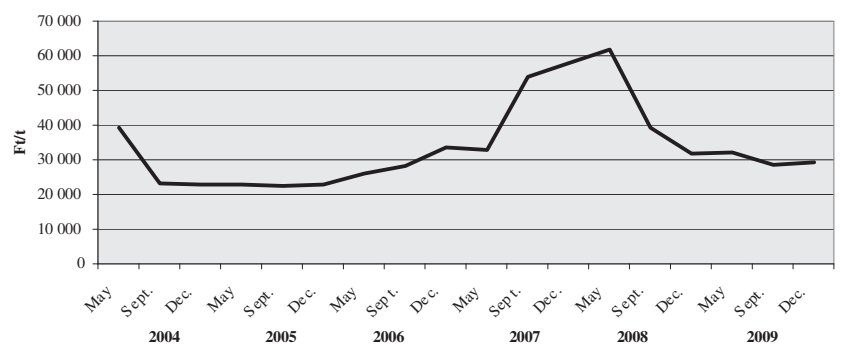

Figure 2: Wheat prices in Hungary 2004-2009.

\subsection{Investigation of the price explosion and collapse in 2007-2008}

After the overview of price information of the examined period let's focus the two critical years 2007 and 2008 from the financing banks point of view. Financing banks in the field of Lombard credits in grain market sustained extremely high loss in this period.

I hereby try to explain the reason of this and try to justify reasonable price risk management with combined use of public warehousing and futures market involved my futures model as technical tool calculations.

According to the charts of two main merchandises of grain market on Figure 3 price trend changing is noticeable.



Figure 3: Prices trend changing in Hungary 2007-2008

In consequence of price decreasing and of course the shortage of suitable risk management strategy financing banks lost high amounts and pulled out from Lombard financing. 


\subsection{Financial risk management based on model calculations}

Based on the on the fact that futures market prices are public and the market institutions are available for all of market participants, included financial banks, it is possible and obligatory to manage price and through this financial risks!

Hereinafter I introduce the suitable price risk strategy from the bank point of view applying futures and spot market prices of the two investigated year and using the model as a calculation tool.

Example: The bank intents to credit a 180 days long period from March to September. The collateral of the credit is the Warehouse Receipt redemption is due in September which has to cover the financial costs.

Creditor has to calculate 180 days price with all of the costs during financing period facing that calculated price must be lower maximum equal of futures price. In this case the creditor has to open a futures selling position on the futures market. The price risk is managed and the credit is in safe position.

To achieve this rule creditor has to use $70-90 \%$ financing price level compared futures prices.

In this example I supposed to become goods owner in the middle of financing period, because of collapsed credit, so costs are calculated for 3 month. Parity is FOB Csepel to simplify the example but the model is able to calculate any other parity and logistical possibility too.

\subsubsection{Model calculations for 2007 and 2008 .}

Hereinafter I introduce model calculations and management strategy based on them. Table 1 shows spot and futures corn prices in 2007.

Table 1: Corn prices, 2007 (Ft/t)

\begin{tabular}{|c|c|c|c|c|c|}
\hline March & May & July & September & November & December \\
\hline 31395 & 30179 & 34214 & 52697 & 54828 & 52545 \\
\hline Futures & 31500 & 31800 & 31500 & 29100 & 29200 \\
\hline
\end{tabular}

Investigated the data of 2007 price increasing of spot prices is remarkable comparing futures prices. Figure 4 shows it graphically.

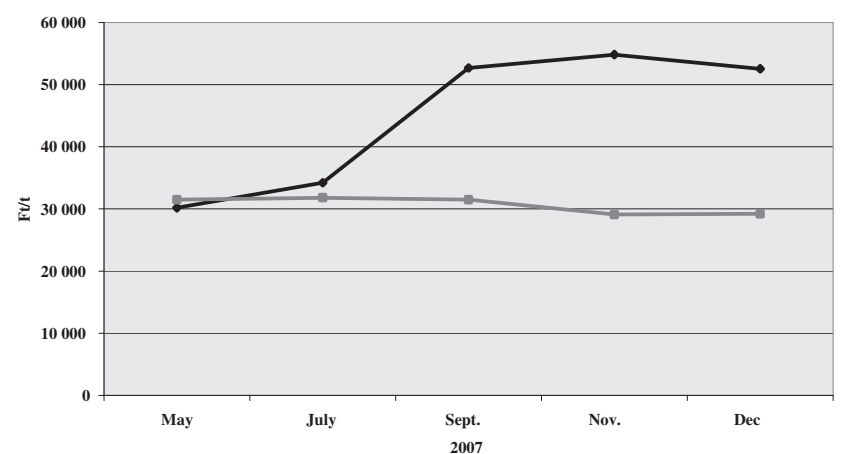

Figure 4: Corn Prices in 2007.
In March the only known price information are futures prices which must be the basis of market strategy. According to the September futures price creditor has to use $28.000 \mathrm{Ft} / \mathrm{t}$ financing price level and hedge it.

Using this financial price as the basis the result of the model calculation is the following:

\section{Calculated 180 days price: $\quad 31.395 \mathrm{Ft} / \mathrm{t}$}

Futures price:

$31.500 \mathrm{Ft} / \mathrm{t}$

Result: Futures price is higher, the risk is managed credit is saved.

Because of extreme price increasing borrowers could repay credits easily, and this is the relevant business decision from their side to realize extra profit. The increasing value of the collateral secures the credit in the moment of liquidation of futures position. Table 1 shows spot and futures corn prices in 2008 .

Table 2: Corn prices, 2008 (Ft/t)

\begin{tabular}{|c|c|c|c|c|c|}
\hline March & May & July & September & November & December \\
\hline 51808 & 47308 & 44920 & 31773 & 22434 & 22024 \\
\hline Futures & 50800 & 51700 & 52700 & 47300 & 47700 \\
\hline
\end{tabular}

Investigated the data of 2008 price increasing of spot prices is remarkable comparing futures prices. Figure 5 shows it graphically.

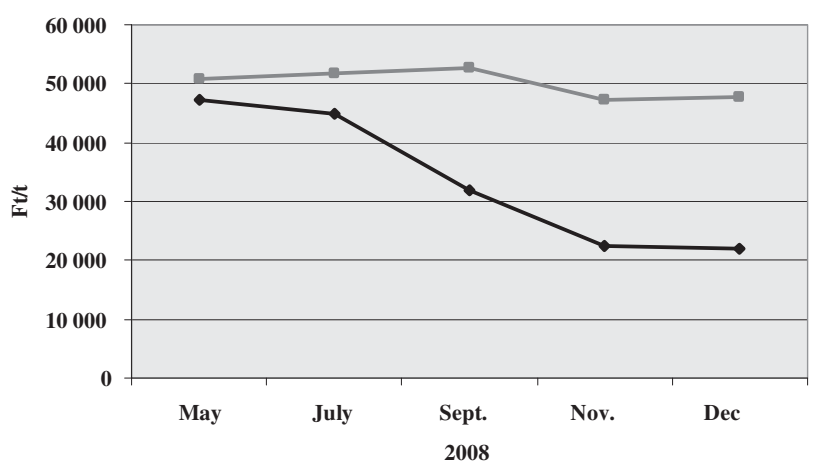

Figure 5: Corn Prices in 2008.

According to the theory of financial business introduced above using price data of Table 2 the financing price can be $48.000 \mathrm{Ft} / \mathrm{t}$ the result of model calculation is the following:

Calculated 180 days price: $\quad 52.645 \mathrm{Ft} / \mathrm{t}$

Futures price: $\quad 52.700 \mathrm{Ft} / \mathrm{t}$

Result: Futures price is higher, the risk is managed credit is saved.

Because of extreme price decreasing value of the collateral collapsed. The profit of hedge position secures the credit in the moment of credit repayment and liquidation of futures position.

\section{Conclusions}

The Specified Futures Model using electronic database is a real practical tool for calculations. The model can present up-to-date information for business decisions based on daily figures. The excel basis helps to be easily available and 
useful for any market participants. The model is suitable for help in case of short term business calculations and building long term market strategies as well.

The institutes as futures exchange and public warehouse give a lot of possibilities in price risk management. The Warehouse Receipt is one of the best collateral in case of Lombard financing and the futures hedge is available price fixing possibility. The real appropriate solution is the combined using.

After presented the most important price trends from the EU assessment in 2004 until these days the reason of financial loss in 2008 was justified.

The proposition from Creditors side was the result of irrelevant marketing strategy without suitable price risk management!

Focused the two extreme years 2007 and 2008 using real spot and futures prices data of this period as the basis of financial strategy building the relevant 180 days long commodity financing construction became effectuated independently of market price risks.

Combined using of market institutes as well as precalculations is necessary for building secure market position.

The model is competent to be practical tool for establish price and credit risk strategy introduced in this paper

\section{References}

Bács, Z. - Kozár, L. (2002): (Facts about Public Warehousing) Amit a közraktározásról tudni kell. Szaktudás Ház Publisher, Budapest

Bács Z.: A közraktározás hasznosságának megítélése modellezéssel. Gazdasági és Társadalomtudományi Közlemények, Krúdy Könyvkiadó Nyíregyháza, 2010.

Bozzai, R. (1988): (Itiner for the Exchange) Tőzsdekalauz. Magyar Tőzsdealapítvány, Budapest

Csőke, A. (1996): (Public Warehousing) A közraktározás. Közgazdasági és Jogi Publisher Home, Budapest

Ertsey I. - Nábrádi A.: Általános vállalkozási alapok. Campus Kiadó, Debrecen, 2003.

Fodor, L. (2002): (Role of Exchanges in Price Formation and Liquidity of Agricultural Commodities) Tőzsdék szerepe a mezőgazdasági termékek áralakításában, likviditásában. Ph.D. thesis, Kaposvár

Kárpáti L. - Csapó Zs.: Marketing és kereskedelem. Campus Kiadó, Debrecen, 2003.

Kemény, G. (2001): (Analysis of Practice of Planning at Agribusineses of S. Dunantul) A tervezési gyakorlat elemzése a Dél-Dunántúli régió mezőgazdasági társas vállalkozásaiban. Ph.D. thesis, Kaposvár

Krugman, P. (1994): Competitiveness: a dangerous obsession. Foreign Affairs, 73.

Nábrádi A. - Nagy A.: Vállalkozások működtetése az Európai Unióban. Szaktudás Kiadó Ház, Budapest, 2007.

Pennings, J. M. E. - Meulenberg, M. T. G. (1997): Hedging Risk in Agricultural Futures Markets. Boston, Kluwer Academic Publishers 
